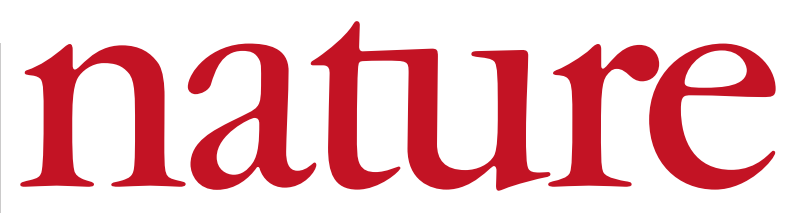

20 November 2003 Volume 426 Issue no 6964

\title{
Facing the nuclear danger
}

The war on terrorism threatens to overshadow the greatest weapons-proliferation challenge of all - the safe management of nuclear materials in the former Soviet Union.

S addam Hussein, Osama Bin Laden and Kim Jong-Il are each well-known for their possible ties to weapons of mass destruction, but has anyone heard of Alexander Tyulyakov? Tyulyakov was deputy director of Atomflot — the state-owned company overseeing Russia's fleet of nuclear icebreakers. In August, he was arrested by the Russian Federal Security Service and charged with trying to sell more than a kilogram of uranium and radium to nuclear smugglers.

When Tony Blair and George W. Bush meet in London this week, it must be hoped that their discussions on the threat of proliferation of weapons of mass destruction will not be confined to the status of weapons programmes in Iraq, North Korea and Iran.

Proliferation experts have argued for years that the kind of activities in which Tyulyakov was allegedly engaged present an immense danger. This was acknowledged soon after the collapse of the Soviet Union, in particular by then senator Sam Nunn (Democrat, Georgia) and Senator Richard Lugar (Republican, Indiana), who cosponsored a 1991 law to support the adequate supervision of nuclear materials there. But it has been difficult for the United States to sustain its commitment to Nunn-Lugar programmes. And European governments have shown even less commitment - lamentably, some of them continue to see this pressing issue as something for the United States and Russia to address (see page 219).

But the problem belongs to all of us and it isn't going away. Its scope spreads far beyond the old Soviet atomic-weapons complex and the nuclear submarines' fuel cycle. Across Russia, for example, hundreds of weather stations and navigation beacons are powered by highly radioactive strontium, which could be used in so-called 'dirty' weapons that spread such materials around without any fission reaction. And shipyards and factories house tonnes of nuclear fuel from ships and power plants. Research reactors in the former Warsaw Pact countries pose another risk. That's aside from the tonnes of biological agents thought to reside in Russian military installations, and the thousands of intact nuclear weapons still deployed or stored in the country.

The Nunn-Lugar act and other salient measures anticipated a prolonged and concerted Western effort to help safeguard these materials. But a report released this week by a coalition of 21 nonproliferation organizations suggests that the effort is in danger of stalling.

The report (see www.sgpproject.org) describes the progress to date of the Global Partnership Against the Spread of Weapons and Materials of Mass Destruction, an initiative launched in June 2002 to secure government commitments of US\$20 billion over ten years to clean up facilities, manage materials and gainfully employ weapons scientists in the former Soviet Union. But in the first year of the partnership, the report says, its 14 member governments spent only about half of the US $\$ 2$ billion needed to meet its goals.

If governments are serious about slowing weapons proliferation, there can be no higher priority than making up this shortfall. And that will only be the start of the decades-long commitment required to contain the Soviet legacy of weapons of mass destruction.

\section{Local support required}

The Royal Society's review of Britain's university funding system should take into account the needs of the regions.

$\mathrm{B}$ ritish universities are, by most measures, doing well in their ability to perform internationally competitive research. But there's a widespread feeling that they could do even better. This week, the Royal Society has called for what it terms a "radical review" of the dual support system, whereby the universities get most of their operating costs from higher-education funding councils, and most of their research money from research councils.

The review is worthwhile, especially given the level of carping that surrounded the most recent attempt to track the performance of university departments, through the higher-education councils' Research Assessment Exercise. That exercise has played a useful role, but seems to have run its course.

So, what next? British universities have recovered from a serious crisis of confidence that reached its nadir about twenty years ago. Lately, their administrators' chief priority has been to emulate the American institutions that continue to poach faculty at a fair clip.

This has involved pestering alumni for cash contributions. Unfortunately, British university graduates with $£ 1,000$ to spare seem more inclined to buy a season ticket to watch Arsenal than to bail out their Alma Mater - even if the former isn't tax-deductible. Attempts to build private sources of funding for British universities — or even to establish private universities - have foundered, meanwhile, on the widespread assumption that university education (and, by extension, university research) is essentially a public function.

So which of the tools that built the US research university are really available to Britain? One that you don't hear much about is the ability of American states to back their own public universities to the hilt. In this way, the likes of the University of Wisconsin-Madison and the University of Arizona at Tucson have been able to build truly world-class departments that can compete for staff and research funds with longer-established institutions on both US coasts.

Despite early pledges from Tony Blair's first government, the English regions have no fiscal power to support vital institutions of their own, such as universities. Business leaders and politicians in and around Manchester, Leeds, Nottingham and Bristol, for example, would like nothing better than to build up local universities, as their counterparts in Germany and the United States are able to do. But they can't. The newly established Scottish parliament is already taking steps to boost its own university system. A similar mechanism is needed in England if the Oxford and Cambridge duopoly is to be replaced with a flexible and genuinely competitive university system. 